\title{
PENGARUH PROMOSI MELALUI MEDIA SOSIAL DAN WORD OF MOUTH TERHADAP VOLUME PENJUALAN PADA MEDIA KOMPUTER DENPASAR
}

\author{
I Ketut Lanus Arianta ${ }^{1}$ \\ I Made Kartika ${ }^{2}$ \\ ${ }^{1,2}$ Fakultas Ekonomi Universitas Ngurah Rai, Bali, Indonesia \\ 1e-mail : lanusarianta.la@gmail.com
}

\begin{abstract}
ABSTRAK
Tujuan penelitian ini adalah untuk mengetahui bagaimanakah pengaruh promosi melalui media sosial dan word of mouth secara parsial terhadap volume penjualan pada Media Komputer Denpasar dan untuk mengetahui bagaimanakah pengaruh promosi melalui media sosial dan word of mouth secara simultan terhadap volume penjualan pada Media Komputer Denpasar. Data dianalisis menggunakan analisis regresi linier berganda, analisis koefisien determinasi, analisis uji t (t-test) dan analisis uji f. Hasil penelitian ini menunjukan 1) Sosial Media dan Word of Mouth secara simultan berpengaruh signifikan terhadap Volume Penjualan 2) Terdapat pengaruh yang positif dan signifikan Sosial Media terhadap Volume Penjualan 3) Terdapat pengaruh yang positif dan signifikan Word of Mouth terhadap Volume Penjualan.
\end{abstract}

Kata kunci : Promosi Melalui Media Sosial, Word Of Mouth, Volume Penjualan

\section{ABSTRACT}

The purpose of this study was to find out how the influence of promotion through social media and word of mouth partially on the sales volume on Media Computer Denpasar and to find out how the influence of promotion through social media and word of mouth simultaneously on sales volume on Media Computer Denpasar. Data were analyzed using multiple linear regression analysis, coefficient of determination analysis, $t$ test analysis (t-test) and test analysis $f$. The results of this study show 1) Social Media and Word of Mouth simultaneously have a significant effect on Sales Volume 2) There is a positive and significant effect of Social Media on Sales Volume 3) There is a positive and significant effect of Word of Mouth on Sales Volume.

Keywords: Promotion Through Social Media, Word Of Mouth, Sales Volume 


\section{PENDAHULUAN}

Di era globalisasi seperti sekarang ini teknologi dan informasi berperan sangat penting dalam memberikan dampak dalam perdagangan bebas seakan-akan perdagangan menjadi tanpa ada batasan. Hal tersebut menyebabkan semakin tinggi pula persaingan yang harus dihadapi oleh semua pihak terutama pihak usaha-usaha kecil selaku produsen. Sebagai produsen, usahausaha kecil ini perlu memikirkan dan menentukan strategi pemasaran agar di minati oleh banyak konsumen. Teknologi yang ada di dunia ini terus mengalami perkembangan yang sangat signifikan dalam berbagai bidang, salah satunya seperti mengikuti perkembangan internet seperti sosial media.

Promosi sebagai unsur utama dalam kampanye pemasaran merupakan kumpulan alat-alat yang insentif yang sebagian besar berjangka pendek, yang dirancang untuk merangsang pembelian produk atau jasa tertentu dengan lebih cepat dan lebih besar oleh konsumen atau pedagang. Promosi merupakan salah satu faktor penentu keberhasilan suatu program pemasaran untuk memberikan informasi mengenai adanya suatu produk.

Dari definisi diatas dapat dikatakan bahwa promosi merupakan cara perusahaan memperkenalkan produknya dan mempengaruhi keputusan pembelian konsumen. Promosi yang disebut juga alat mengkomunikasikan produk telah mengalami perkembangan dimana pemasar lebih mudah dan lebih cepat dalam mempromosikan produknya. Hal ini disebabkan munculnya berbagai media baru yang dapat dimanfaatkan untuk menjangkau konsumen lebih cepat dan luas.

Keberhasilan perusahaan dalam menghadapi persaingan merupakan indikator dari kelangsungan hidup perusahaan. Kebijakan tersebut meliputi kebijakan penentuan harga, kebijakan pemilihan produk, kebijakan penetuan promosi yang penentuan harga, kebijakan pemilihan produk, kebijakan penentuan promosi yang paling efektif dan efisien, kebijakan pemilihan saluran distribusi yang paling tepat. Karena hal ini sangat mempengaruhi perilaku konsumen untuk memberli produk perusahaan yang akhirnya akan meningkatkan volume penjualan pada perusahaan.

Kehadiran media sosial pertama kali diawali dengan munculnya Sixdegress.com pada tahun 1997 sebagai situs jejaring sosial pertama kali di dunia. Pada tahun 1999 dan tahun 2000 mulai muncul situs jejaring sosial bernama Lunarstrom, Live Journal, dan Cyword dengan sistem informasi searah. Tahun 2003 mulai bermunculan situs jejaring sosial yang lain dengan berbagai macam katagori seperti Flikr, Youtube, Myspace, dan Friendster. Kemudian pada tahun 2006, kehadiran Facebook langsung menggeser posisi jejaring sosial pada saat itu. Facebook yang diluncurkan pada tahun 2004 itu saat ini telah memiliki lebih dari 750 juta pengguna. Pada tahun 2011 muncul lagi jejaring sosial baru bernama Google yang dibuat oleh perusahaan internet raksasa, Google. Jejaring sosial ini sepertinya sengaja dibuat untuk menyaingi situs milik Mark Zukerberg. Google memiliki tampilan seperti halnya di Facebook. Jejaring sosial ini yang di gadang-gadang akan menyaingi Facebook milik Mark Zukerberg. 
Pembicaraan orang lain terhadap suatu produk menjadi bagian dari pertimbangan konsumen untuk memilihsuatu produk. Evaluasi alternatif dilakukan konsumen pada saat akan melakukan keputusan pembelian dengan word of mouth yang paling menarik. Konsumen cenderung lebih mempercayai penilaian dari orang lain dalam menilai sebuah produk. Cerita dan pengalaman seseorang menggunakan sebuah produk terdengar lebih menarik yang bisa mempengaruhi pendengarnya untuk ikut mencoba produk tersebut.

Volume penjualan memiliki arti penting yaitu besarnya kegiatan-kegiatan yang dilakukan secara efektif oleh penjualan untuk mendorong agar konsumen melakukan pembelian. Dan tujuan dari volume penjualan ini adalah untuk memperkirakan besarnya keuntungan yang diterima dengan menjual produk kepada konsumen serta biaya yang sudah di keluarkan. Naik turunnya volume penjualan perusahaan dapat dilihat dari intensitas pembelian konsumen dan area perusahaan.

Media Computer berdiri pada tanggal 15 Maret 2015. Pertama kali berdiri, perusahaan ini bergerak di bidang usaha jual beli laptop. Pada tahun 2015, I Made Arsana, owner dari Media Computer, sadar akan keterbutuhan pasar Komputerisasi yang tidak hanya dalam masalah pengadaan, tetapi juga service maintenance, maka Media Computer melakukan ekspansi sebagai perusahaan yang juga melayani service maintenance Computer. Seiring dengan perkembanan teknologi sekarang Media Computer juga melayani jasa perakitan PC (Personal Computer) Custom.

Berdasarkan uraian di atas maka tertarik penulis untuk membuat penulisan lebih lanjut dengan judul : "Pengaruh Promosi Melalui Media
Sosial Dan Word Of Mouth Terhadap Volume Penjualan Pada Media Komputer Denpasar" menjadi sebesar Rp. 32,547,127 dibandingkan tahun 2016 sebesar Rp. 111,331,245.

Melihat kondisi dari laporan arus kas Koperasi Kredit Sedana Padang Asri di atas, sesungguhnya siklus hidup perusahaan dihadapkan pada masalah kedekatan asset dan kewajiban pada kas atau likuiditas perusahaan yang merupakan ukuran kemampuan untuk membayar kewajiban saat jatuh tempo.

Ketika melakukan analisis terhadap suatu perusahaan penting untuk menilai arus kas bersih yang dihasilkan perusahaan selama satu periode tertentu. Melalui analisis ini dapat dinilai kemungkinan perusahaan dalam menghasilkan kas dimasa yang akan datang dan kemampuan perusahaan untuk membayar kewajiban hutang jangka pendek maupun hutang jangka panjang.

\section{METODE PENELITIAN}

Desain penelitian yang digunakan dalam penelitian ini adalah desain kualitatif data yang berhubungan dengan kategori, karakteristik berupa atau berupa kata-kata. Data kuantitatif dalam penelitian ini adalah angka-angka yang terdapat pada skor jawaban responden pada Media Computer Denpasar. Populasi penelitian ini adalah jumlah rata-rata konsumen Media Computer selama 3 bulan terakhir, yaitu 287 orang. Sampel adalah sejumlah karakteristik yang dimiliki oleh populasi yang digunakan untuk penelitian. Bila populasi besar, peneliti tidak mungkin mengambil semua untuk penelitian misal karena terbatasnya dana, tenaga dan waktu, maka peneliti dapat menggunakan sampel yang diambil dari populasi itu. Metode penentuan sampel 
ini menngunakan Simple Random Sampling. Simple Random Sampling dinyatakan simple (sederhana) karena pengambilan sampel anggota populasi dilakukan secara acak tanpa memperhatikan strata yang ada dalam populasi itu. Teknik pengumpulan data yang dipergunakan dalam penelitian ini meliputi: observasi, wawancara/interview, kuesioner/angket, dan studi kepustakaan. Setiap jawaban kuesioner mempunyai bobot atau skor nilai dengan skala Likert sebagai berikut : SKB (sangat kurang baik) $=$ skor $1, \mathrm{~KB}$ (kurang baik) $=$ skor 2, CB (cukup baik) $=$ skor $3, \mathrm{~B}$ (baik) = skor 4 dan $\mathrm{SB}$ $($ sangat baik $)=$ skor 5 . Teknik analisis data dalam penelitian ini menggunakan pendekatan kuantitatif yaitu analisis statistik inferensial, terdiri dari: uji asumsi klasik, analisis regresi linier berganda, analisis korelasi berganda, analisis determinasi, uji signifikansi parsial (t-test) dan uji signifikansi simultan (Ftest).

\section{HASIL DAN PEMBAHASAN}

Analisis regresi linier dapat digunakan untuk mengetahui bagaimana pengaruh variabel bebas (Independent) yaitu promosi melalui media sosial (X1), dan word of mouth (X2) terhadap variabel terikat (Dependent) volume penjualan (Y) pada Media Computer Denpasar.

Tabel 1

Hasil Analisis Regresi Liner Berganda

\begin{tabular}{|c|c|c|c|c|c|}
\hline \multirow[b]{3}{*}{ Model } & \multicolumn{3}{|c|}{ Coefficients $^{a}$} & \multirow[b]{3}{*}{$t$} & \multirow[b]{3}{*}{ Sig. } \\
\hline & \multicolumn{2}{|c|}{$\begin{array}{c}\text { Unstandardized } \\
\text { Coefficients }\end{array}$} & \multirow{2}{*}{$\begin{array}{c}\begin{array}{c}\text { Standardized } \\
\text { Coefficients }\end{array} \\
\text { Beta }\end{array}$} & & \\
\hline & B & $\begin{array}{l}\text { Std. } \\
\text { Error }\end{array}$ & & & \\
\hline 1 (Constant) & $-10,517$ & 1,941 & & $-5,417$ & $\begin{array}{r}, 00 \\
0\end{array}$ \\
\hline $\mathrm{X} 1$ & ,678 & ,089 & ,524 & 7,630 & $\begin{array}{r}, 00 \\
0\end{array}$ \\
\hline $\mathrm{x} 2$ & ,533 & ,076 & ,481 & 6,995 &, 00 \\
\hline
\end{tabular}

a. Dependent Variable: $Y$

Sumber : Data diolah menggunakan SPSS, 2019.

Berdasarkan tabel 1 dapat disusun persamaan regresi yaitu sebagai berikut :

Dari persamaan tersebut dapat dijelaskan bahwa nilai konstanta ( ) sebesar -10,517 menyatakan bahwa apabila variabel Sosial Media (X1) dan Word of Mouth (X2) sama dengan nol, maka nilai Volume Penjualan (Y) adalah sebesar $-10,517$ satuan. Namun dalam rentangan seluruh data yang diperoleh tidak terdapat nilai nol, sehingga model ini tidak dapat digunakan untuk memprediksi nilai variabel $\mathrm{Y}$ saat nilai seluruh variabel bebasnya adalah nol.

Nilai koefisien $\beta 1=0,678$ menunjukkan bahwa terdapat pengaruh positif antara variabel Sosial Media (X1) terhadap variabel Volume Penjualan (Y) sebesar 0,678 . Hal ini berarti apabila variabel Sosial Media (X1) naik sebesar 1 satuan dan nilai variabel bebas lainnya adalah konstan, maka nilai variabel Volume Penjualan (Y) akan mengalami peningkatan sebesar 0,678 satuan. 
Nilai koefisien $\beta 2=0,533$ menunjukkan bahwa terdapat pengaruh positif antara variabel Word of Mouth (X2) terhadap variabel Volume Penjualan (Y) sebesar 0,533 . Hal ini berarti apabila variabel Word of Mouth (X2) naik sebesar 1 satuan dan nilai variabel bebas lainnya adalah konstan, maka nilai variabel Volume Penjualan (Y) akan mengalami peningkatan sebesar 0,533 satuan. a. Analisis Koefisien Determinasi

Analisis ini bertujuan untuk mengetahui atau menentukan seberapa besar sumbangan (kontribusi) promosi melalui media sosial terhadap keputusan pembelian di Media Computer Denpasar yang dinyatakan dalam presentase.

Tabel 2

Model Summary

\begin{tabular}{|l|l|l|l|l|}
\hline Model & $R$ & $\begin{array}{l}\mathrm{R} \\
\text { Square }\end{array}$ & $\begin{array}{l}\text { Adjusted } \mathrm{R} \\
\text { Square }\end{array}$ & Std. Error of the Estimate \\
\hline 1 &, $856^{\mathrm{a}}$ &, 733 &, 726 & 1,44208 \\
\hline
\end{tabular}

a. Predictors: (Constant), X2, X1

b. Dependent Variable: $Y$

Sumber : Data diolah menggunakan SPSS, 2019.

Berdasarkan tabel 4 menunjukan besarnya nilai $\mathrm{R}$ Square (R2) adalah 0,733. atau 73,3\%. Angka 73,3\% mempunyai makna besarnya pengaruh variabel Sosial Media (X1) dan Word of Mouth (X2) secara bersama-sama atau gabungan terhadap Volume Penjualan (Y). Sedangkan sisanya sebesar $26,7 \%$ disebabkan oleh variabel lain di luar penelitian ini.

\section{Analisis Uji Statistik t (t-test)}

Uji ini digunakan untuk menguji signifikansi koefisien regresi, sehingga diketahui signifikansi pengaruh promosi melalui media sosial terhadap keputusan pembelian.

Hipotesis

HO : (Variabel bebas ke-i tidak berpengaruh signifikan terhadap variabel terikat)

H1 : (Variabel bebas ke-i berpengaruh signifikan terhadap variabel terikat) (dengan $\mathrm{i}=1,2,3$ )

Tingkat signifikansi : 0,05

Keputusan Uji : tolak H0 jika

nilai sig. variabel ke-i $<0,05$ 
Tabel 3

Hasil Analisis Uji t-test

\begin{tabular}{|c|c|c|c|c|c|}
\hline \multirow[b]{3}{*}{ Model } & \multicolumn{4}{|c|}{ Coefficients $^{a}$} & \\
\hline & \multicolumn{2}{|c|}{$\begin{array}{c}\text { Unstandardiz } \\
\text { ed } \\
\text { Coefficients }\end{array}$} & $\begin{array}{c}\text { Standardize } \\
\mathrm{d} \\
\text { Coefficient } \\
\mathrm{s} \\
\end{array}$ & \multirow[b]{2}{*}{$\mathrm{T}$} & \multirow[b]{2}{*}{ Sig. } \\
\hline & B & $\begin{array}{c}\text { Std. } \\
\text { Error }\end{array}$ & Beta & & \\
\hline $\begin{array}{r}1 \text { (Con } \\
\text { stant) }\end{array}$ & $\begin{array}{r}10,51 \\
7\end{array}$ & 1,941 & & 5,417 &, 000 \\
\hline $\mathrm{X} 1$ & 678 & ,089 &, 524 & 7,630 &, 000 \\
\hline $\mathrm{X} 2$ & ,533 & 076 & ,481 & 6,995 &, 000 \\
\hline
\end{tabular}

a. Dependent Variable: $\mathrm{Y}$

Sumber : Data diolah menggunakan SPSS, 2019

Berdasarkan tabel 3 diketahui bahwa variabel Sosial Media (X1) mempunyai nilai sig. 0,000 < 0,05 maka Ho ditolak dan H1 diterima. Artinya, secara parsial variabel Sosial Media berpengaruh positif dan signifikan terhadap Volume Penjualan. Dengan kata lain, semakin baik Sosial Media maka semakin baik Volume Penjualan.

Gambar 1

Daerah penerimaan dan penolakan Ho

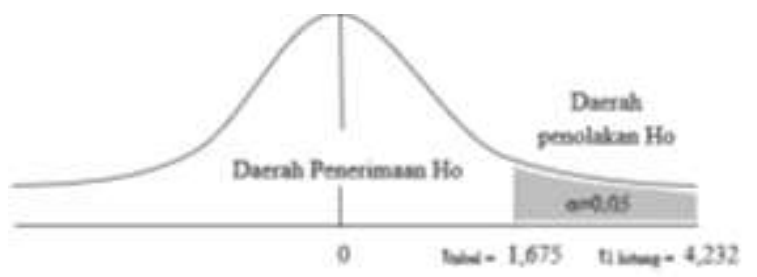

Sumber : Data yang diolah, 2019

Variabel Word of Mouth (X2) mempunyai nilai sig. $0,000<0,05$ maka Ho ditolak dan $\mathrm{H} 1$ diterima. Artinya, secara parsial variabel Word of Mouth
(X2) berpengaruh positif dan signifikan terhadap Volume Penjualan. Dengan kata lain, Semakin baik Word of Mouth maka semakin baik Volume Penjualan. 
Gambar 2

Daerah penerimaan dan penolakan Ho

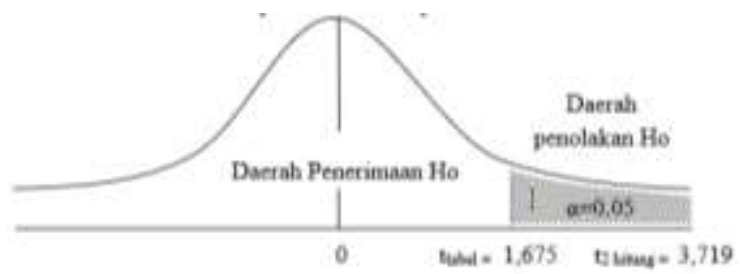

Sumber : Data yang diolah, 2019

Analisis Uji F

Pengujian hipotesis pengaruh secara simultan antara variabel independen dengan variabel dependen dilakukan dengan membandingkan nilai sig. pada tabel ANOVA dengan tingkat signifikansi 0,05. Output SPSS 23 adalah sebagai berikut :

Tabel 4

Hasil Analisis Uji F

\begin{tabular}{|c|c|c|c|c|c|}
\hline \multicolumn{6}{|c|}{ ANOVA $^{a}$} \\
\hline Model & $\begin{array}{c}\text { Sum of } \\
\text { Square } \\
\text { s }\end{array}$ & Df & $\begin{array}{l}\text { Mean } \\
\text { Square }\end{array}$ & F & Sig \\
\hline $1 \underset{n}{ }$ Regressio & $\begin{array}{r}405,75 \\
3\end{array}$ & 2 & 202,877 & $\begin{array}{r}97,5 \\
55\end{array}$ & $\begin{array}{r}, 00 \\
0^{\mathrm{b}}\end{array}$ \\
\hline Residual & $\begin{array}{r}147,65 \\
2\end{array}$ & 71 & 2,080 & & \\
\hline Total & $\begin{array}{r}553,40 \\
5\end{array}$ & 73 & & & \\
\hline
\end{tabular}

a. Dependent Variable: Y

b. Predictors: (Constant), X2, X1

Sumber : Data diolah menggunakan SPSS, 2019

Berdasarkan Tabel ANOVA tersebut diketahui bahwa nilai nilai sig. adalah $0,000<0,05$ maka Ho ditolak dan $\mathrm{H} 1$ diterima. Artinya, secara simultan variabel variabel Sosial Media (X1) dan Word of Mouth (X2) berpengaruh signifikan terhadap Volume Penjualan (Y) 
Gambar 3

Daerah penerimaan dan penolakan Ho

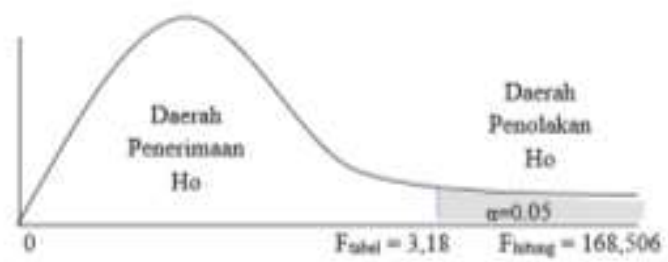

Berdasarkan hasil penelitian telah diperoleh, maka interpretasinya adalah:

Dari hasil analisis regresi linier berganda, nilai koefisien $\beta 1=0,678$ menunjukkan bahwa terdapat pengaruh positif antara variabel Sosial Media (X1) terhadap variabel Volume Penjualan (Y) sebesar 0,678. Nilai koefisien $\beta 2=0,533$ menunjukkan bahwa terdapat pengaruh positif antara variabel Word of Mouth (X2) terhadap variabel Volume Penjualan (Y) sebesar 0,533 .

Hasil analisis koefisien determinasi menunjukan besarnya nilai $\mathrm{R}$ Square (R2) adalah 0,733. atau 73,3\%. Angka $73,3 \%$ mempunyai makna besarnya pengaruh variabel Sosial Media (X1) dan Word of Mouth (X2) secara bersama-sama atau gabungan terhadap Volume Penjualan (Y). Sedangkan sisanya sebesar $26,7 \%$ disebabkan oleh variabel lain di luar penelitian ini.

Hasil analisis uji t (t-test) menunjukan bahwa secara parsial variabel Sosial Media berpengaruh positif dan signifikan terhadap Volume Penjualan, dengan kata lain, semakin baik Sosial Media maka semakin baik Volume Penjualan. Dan secara parsial variabel Word of Mouth (X2) berpengaruh positif dan signifikan terhadap Volume Penjualan. Dengan kata lain, Semakin baik Word of Mouth maka semakin baik Volume Penjualan.
Hasil uji $\mathrm{F}$ menunjukan bahwa secara simultan variabel variabel Sosial Media (X1) dan Word of Mouth (X2) berpengaruh signifikan terhadap Volume Penjualan (Y).

\section{PENUTUP \\ KESIMPULAN}

Berdasarkan uraian yang telah dipaparkan pada bab - bab sebelumnya maka dapat disimpulkan bahwa :

a. Sosial Media dan Word of Mouth secara simultan berpengaruh signifikan terhadap Volume Penjualan

b. Terdapat pengaruh yang positif dan signifikan Sosial Media terhadap Volume Penjualan

c. Terdapat pengaruh yang positif dan signifikan Word of Mouth terhadap Volume Penjualan.

\section{SARAN-SARAN}

Dari kesimpulan yang telah diuraikan diatas, maka selanjutnya dapat diberikan saran yaitu sebagai berikut: Adapun saran yang dapat disampaikan berdasarkan hasil penelitian yang telah dilaksanakan adalah sebagai berikut.:

Berdasarkan rata-rata skor pada variabel Promosi melalui media sosial dimana secara keseluruhan responden mempunyai persepsi yang paling kecil terhadap item pernyataan "Media Computer sangat ramah dalam melayani 
konsumen". Maka Manajemen Media Computer kedepannya dapat lebih meningkatkan pelayanan terutama keramahan terhadap konsumen.

Berdasarkan rata-rata skor pada variabel Word Of Mouth dimana secara keseluruhan responden mempunyai persepsi yang paling kecil terhadap item pernyataan "Saya pernah mendengar hal-hal positif tentang Media Computer". Maka Manajemen Media Computer kedepannya dapat lebih meningkatkan kepercayaan terutama hal-hal positif kepada konsumen.

Berdasarkan rata-rata skor pada variabel Volume Penjualan dimana secara keseluruhan responden mempunyai persepsi yang paling kecil terhadap item pernyataan "Lokasi penjualan Media Computer sangat strategis". Maka Manajemen Media Computer kedepannya dapat merencanakan kembali lokasi yg tepat dan strategis untuk konsumen demi meningkatkan volume penjualan pada perusahaan.

\section{DAFTAR PUSTAKA}
Baswir,Revisond. (2013). Koperasi Indonesia. Edisi Kedua. Yogyakarta: BPFE.

Carl S. Warren, et al. (2014). Accounting Indonesia Adaptation. Jakarta : Salemba Empat.

Fahmi, Irham. (2014). Pengantar Manajemen Keuangan. Bandung: Alfabeta

Hanafi, Mamduh M. dan Abdul Halim.( 2014). Analisis Laporan Keuangan. Edisi tujuh, Yogyakarta : UPP AMP YKPN.

Hani, Syafrida. (2015). Teknik Analisa Laporan Keuangan. Medan :In Media.
Hery. (2015). Analisis Laporan Keuangan. Edisi 1. Yogyakarta: Center For. Academic Publishing Services.

Ikatan Akuntansi Indonesia. (2013). PSAK No. 2(Revisi 2013). Jakarta : IAI

Ikatan Akuntansi Indonesia. PSAK No. 2 Tentang Laporan Arus Kas- edisi revisi (2014). Penerbit Dewan Standar Akuntansi Keuangan: PT. Raja Grafindo

Ikatan Akuntan Indonesia. (2015). Pernyataan Standar Akuntansi Keuangan. Jakarta : Ikatan Akuntan Indonesia

Kartasapoetra, G., et al. (2013). Koperasi Indonesia. Jakarta: PT Rineka Cipta.

Kasmir. (2014). Analisis Laporan Keuangan. Edisi Satu. Cetakan Ketujuh. Jakarta : PT Raja Grafindo Persada.

Muljono, Djoko. (2013). Buku Pintar Strategi Bisnis Koperasi Simpan Pinjam. Yogyakarta: Andi

Rudianto. (2015). Akuntansi Koperasi. Edisi Kedua. Jakarta: Erlangga.

Sudana, I Made. (2015). Manajemen Keuangan Perusahaan. Edisi Kedua. Jakarta : Erlangga

Sudarwanto, Adenk. (2013). Akuntansi Koperasi. Yogyakarta: Graha Ilmu

Sugiyono. (2014). Metode Penelitian Pendidikan Pendekatan Kuantitatif, Kualitatif dan Kombinasi (Mixed. Methods). Bandung: Alfabeta

Sugiyono. (2016). Metode Penelitian Kuantitatif, Kualitatif dan R\&D. Bandung: PT Alfabet.

Undang-Undang tentang Perkoperasian Nomor 17 Tahun 2012. 
Afiq, Syahrul. (2017). Analisis Laporan Arus Kas Untuk Mengukur Likuiditas Pada Ksu. Sri Lestari ( Studi Kasus Pada Ksu. Sri Lestari Udanawu ). Simki-Economic Vol. 02 No. 03 Tahun 2018 ISSN : 2599-0748

Debby Mogi, Chintia dkk. (2016). Analisa Laporan Arus Kas Sebagai Dasar Pengukuran Likuiditas Pada Perusahaan "Unicare" Cabang Manado. Jurnal Berkala Ilmiah Efisiensi Volume 16 No. 01 Tahun 2016

Diah Rahayu, Nurvita. (2015). Analisis Arus Kas Dalam Menentukan Tingkat Likuiditas Perusahaan (Studi Kasus pada Koperasi Jasa Keuangan Syariah (KJKS) Mawar Karanggeneng, Kabupaten Lamongan Periode Januari Oktober 2013). Jurnal Akuntansi Integratif Vol. 1, No.1, April 2015

Mustakim dkk. (2016). Analisis Arus Kas Dalam Menentukan Tingkat Likuiditas Perusahaan Pada PT. Pelabuhan Indonesia (PELINDO) III Cabang Celukan Bawang. eJournal Universitas Pendidikan Ganesha Jurusan Akuntansi Program S1(Vol: 6 No: 3 Tahun 2019 